\title{
FLOWSHEET FOR COPROCESSING URANIUM AND PLUTONIUM
}

by

\author{
M. A. STATTON AND M. C. THOMPSON
}

Approved by

M. L. Hyder, Research Manager

Separations Chemistry Division

NOTICE

This report contains information of a preliminary nature and was prepared primarily for internal use at the originating installation. It is subject to revision or correction and therefore does not represent a final report. It is passed to the recipient in confidence and should not be abstracted or further disclosed without the approval of the arigstracted or further disclosed without the approval of the originating installation or USDOE Technical Information Center, Oak Ridge, TN 37830.

Publication Date: January 1979

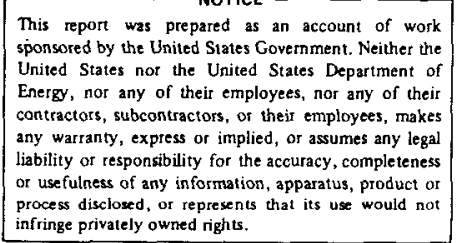

APPLIED TECHNOLOGY

E. I. DU PONT DE NEMOURS AND COMPANY

SAVANNAH RIVER LABORATORY AIKEN, SOUTH CAROLINA 29801

PREPARED FOR THE U. S. DEPARTMENT OF ENERGY UNDER CONTRACT AT(07-2)-1

Fulerert fi. Ansuncernent in ALDK.

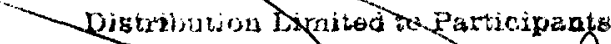
in the Eual Cych Program. Others Reque from nxo. 


\section{DISCLAIMER}

This report was prepared as an account of work sponsored by an agency of the United States Government. Neither the United States Government nor any agency Thereof, nor any of their employees, makes any warranty, express or implied, or assumes any legal liability or responsibility for the accuracy, completeness, or usefulness of any information, apparatus, product, or process disclosed, or represents that its use would not infringe privately owned rights. Reference herein to any specific commercial product, process, or service by trade name, trademark, manufacturer, or otherwise does not necessarily constitute or imply its endorsement, recommendation, or favoring by the United States Government or any agency thereof. The views and opinions of authors expressed herein do not necessarily state or reflect those of the United States Government or any agency thereof. 


\section{DISCLAIMER}

Portions of this document may be illegible in electronic image products. Images are produced from the best available original document. 


\section{ABSTRACT}

A coprocessing solvent extraction flowsheet for recovering and purifying LWR fuels has been altered to achieve partial partioning of uranium and plutonium to eliminate streams with pure plutonium. Partial partitioning has been demonstrated in the laboratory with simulated feeds and irradiated LWR fuel solutions. Hydroxylamine nitrate was the reductant in these tests. Plutonium was concentrated by factors of 6 to 27.4. Tests have shown that 1 to 2 plutonium atoms are reduced for each hydroxylamine molecule consumed. Nitrite interferes with the reduction of plutonium, unless the hydroxylamine concentration is increased. 
CONTENTS

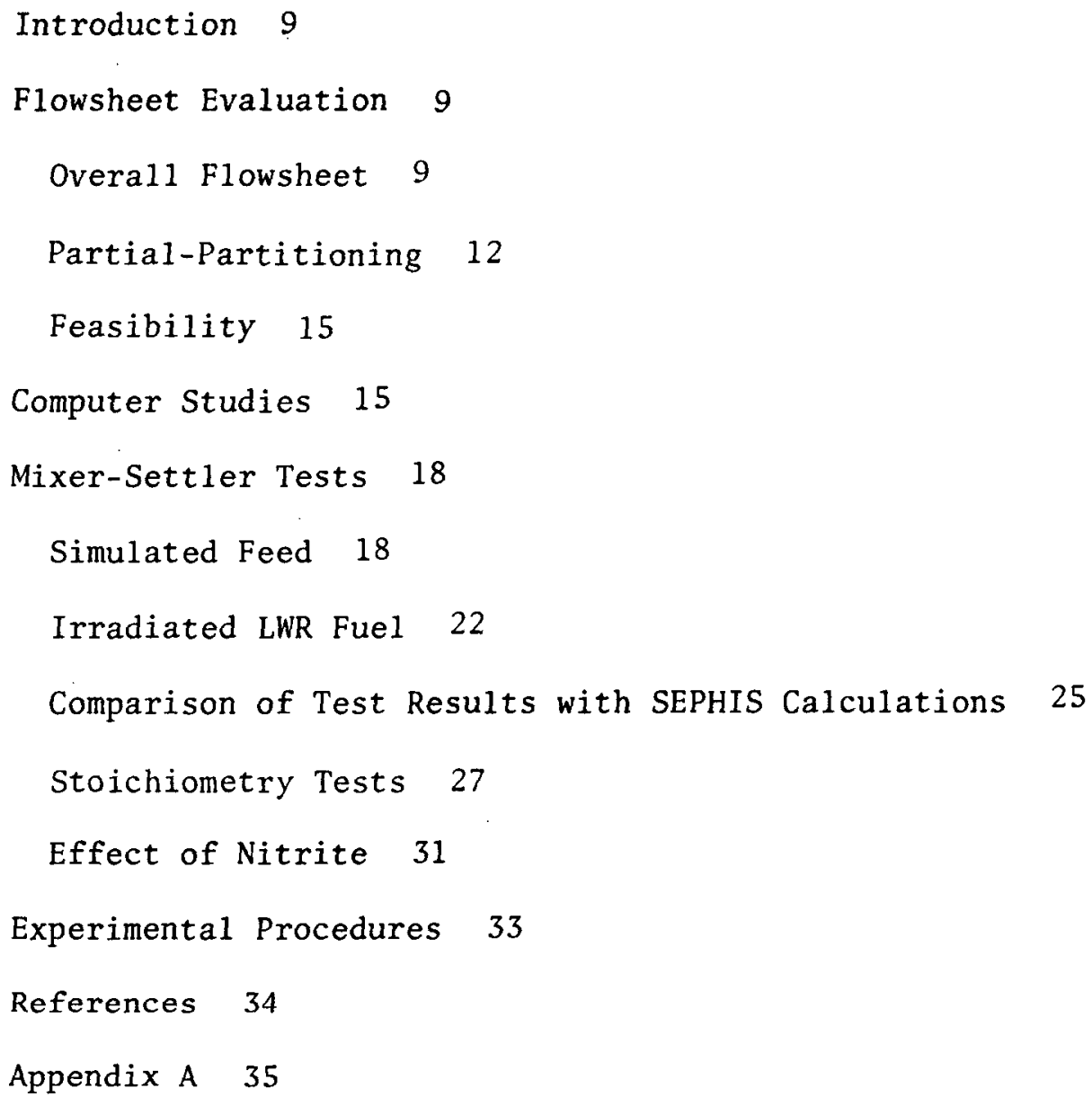


1 Effect of Process Variables in B Mixer-Settler 17

2 A Mixer-Settler Operating Conditions for All Tests with Simulated Feed 19

3 B Mixer-Settler Operating Conditions for Tests with Simulated Feed 19

4 Results of Tests with Simulated Feed 21

5 Oconee-1 Feed Composition 22

6 B Mixer-Settler Operating Conditions for Tests with Oconee-1 Fue 122

7 Results of Tests with Oconee-1 Fuel 23

8 Plutonium Content of the BP and BU Product Streams During the LWR-1 Test 24

9 Calculated and Observed Concentration Factors 26

10 Operating Conditions for Stoichiometry Tests 28

11 Effect of HAN/Pu Ratio on \% Pu Loss 31

12 Effect of Nitrite $-0.007 \mathrm{M} \mathrm{HNO}_{2}$ in $\mathrm{BF} 31$ 


\section{LIST OF FIGURES}

1 Coprocessing Solvent Extraction Flowsheet 10

2 Alternative Arrangement of the Coprocessing Flowsheet 11

3 Partial Partitioning with Hydroxylamine Nitrate 12

4 Alternative Operational Modes for Coprocessing Uranium and Plutonium in B Contactor 14

5 Plutonium Concentration Factors Calculated by SEPHIS 18

6 Observed Equilibration of Plutonium in B Mixer-Settler Product Streams 21

7 Plutonium Profiles in B Mixer-Settler During Test LWR-1 and Simulated Test 224

8 Effect of Extractant Flow Rate on Plutonium Concentration Factor in B Mixer-Settler 27

9 Organic Plutonium Profiles in B Mixer-Settler at Different HAN/Pu Ratios 29

10 Aqueous Plutonium Profiles at Different HAN/Pu Ratios 30

11 Effect of Nitrite on Plutonium Profiles in B Mixer-Settler 32 


\section{FLOWSHEET FOR COPROCESSING URANIUM AND PLUTONIUM}

\section{INTRODUCTION}

To reduce the potential for unauthorized diversion of plutonium, the solvent extraction flowsheet for recovery and purification of LWR fuels is being altered. This alteration will eliminate streams containing pure plutonium. At Savannah River Laboratory, coprocessing is being considered as one option. In coprocessing, a part of the uranium is left mixed with the plutonium. The partitioning step is converted to a partial-partitioning step which results in one pure uranium product stream and one mixed uranium-plutonium product stream. Coprocessing has the advantage that 1) the bulk of the uranium can be processed separately from any plutonium or fission products with only minimum shielding; 2) the flowsheet can be designed to compensate for differences in feed composition so that a constant product is obtained. The extreme case of coprocessing, in which no uranium is separated from plutonium, is unattractive from economic and operational considerations.

The overall objective of the Savannah River Laboratory (SRL) coprocessing program was to develop the details of a coprocessing scheme. The specific goals were to

- design a coprocessing flowsheet

- demonstrate the technical feasibility of the flowsheet in laboratory tests

- define operating conditions

This report describes the overall coprocessing flowsheet and the development of a partial-partitioning flowsheet. Also included are results from computer studies simulating solvent extraction conditions and miniature mixer-settler tests with simulated feed and irradiated LWR fuel.

\section{FLOWSHEET EVALUATION}

\section{Overall Flowsheet}

The reference flowsheet for the overall solvent extraction process for coprocessing is shown in Figure 1. The first cycle 
Ist Cycle

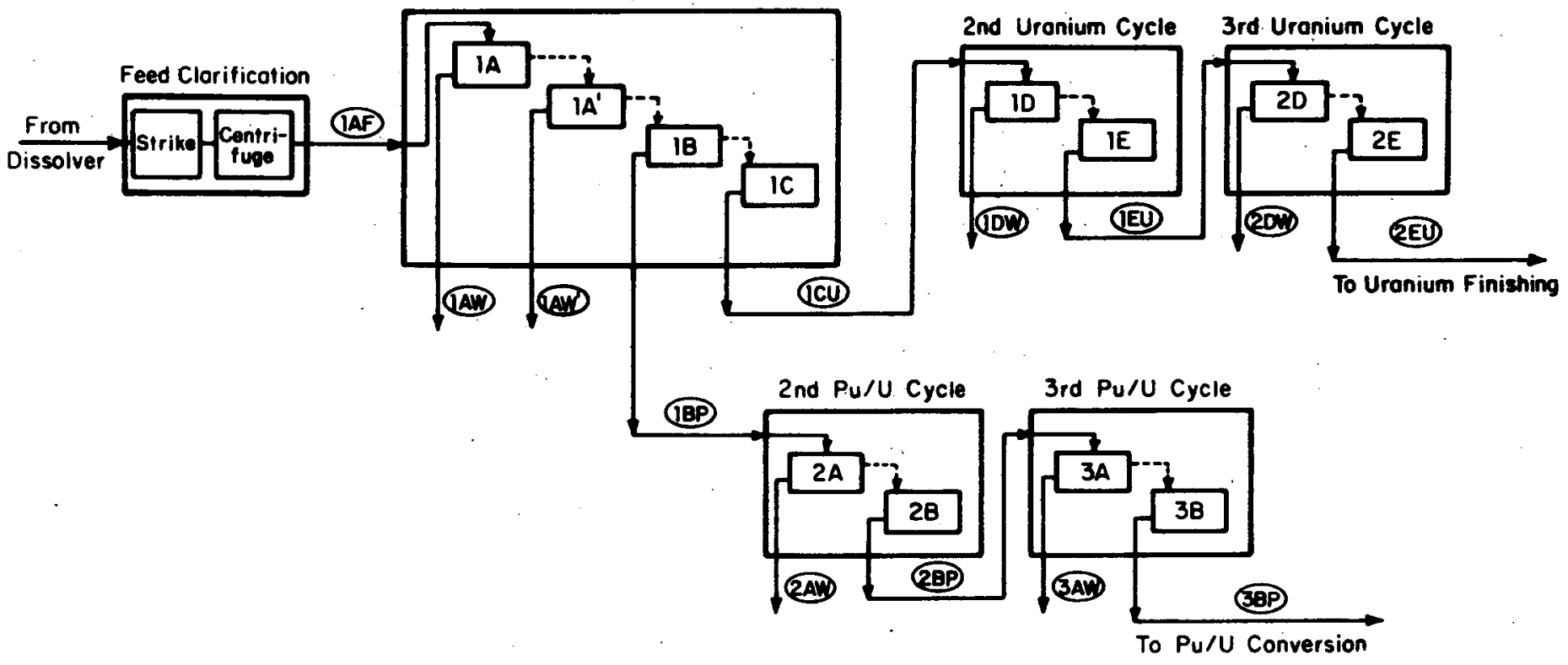

FIGURE 1. Coprocessing Solvent Extraction Flowsheet 
is made up of an extraction step, a scrub step to improve fission product decontamination, a partial-partioning step, and a strip step for the uranium. The first cycle is followed by two additional purification cycles for the uranium product and two cycles for the mixed uranium-plutonium product, each of which consists of extracting and stripping. This flowsheet differs from conventional LWR reprocessing flowsheets only in the operation of the partial-partition contactor, and the second and third mixed uranium-plutonium cycles.

An alternative arrangement of the coprocessing flowsheet is shown in Figure 2. This arrangement has two advantages:

1) No further processing of the uranium-plutonium stream is required after partial partitioning in the 2B contactor; consequently, no alteration of the plutonium/uranium ratio by subsequent solvent-extraction cycles could occur.

2) Three fewer contactors and two fewer solvent-purification systems would be needed than in the reference solventextraction flowsheet (Figure 1).
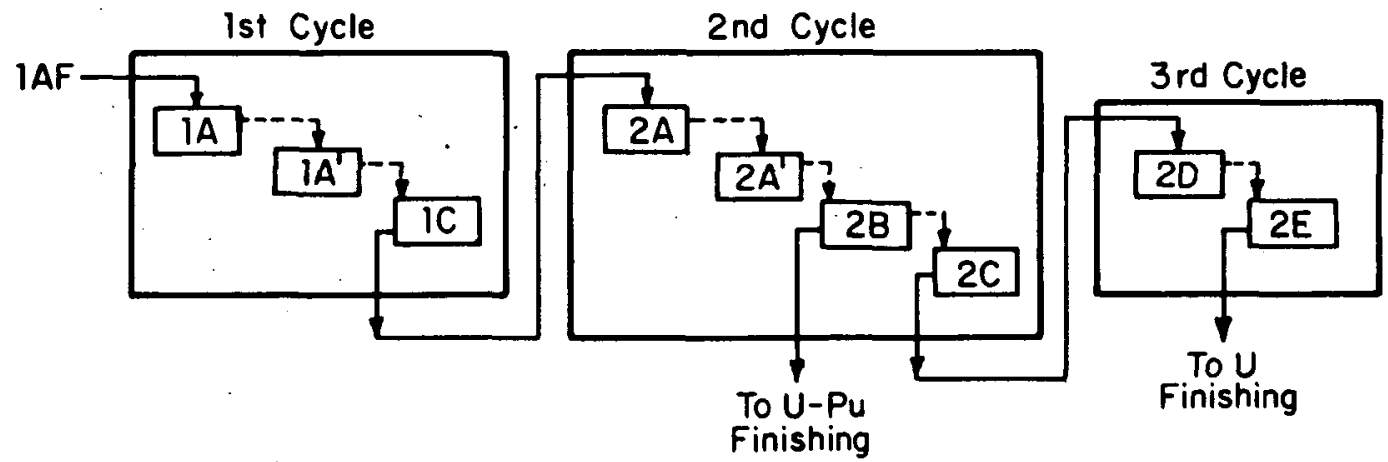

FIGURE 2. Alternative Arrangement of the Coprocessing Flowsheet

The disadvantage with the alternative coprocessing flowsheet is that a third cycle of solvent extraction of the pure uranium stream may be insufficient to achieve a plutonium decontamination factor of $2-4 \times 10^{8}$, which is needed to meet the proposed specification of 25 to 50 alpha dis/(min-g U). Although it may be possible to obtain the required decontamination factor by increasing the number of stages in the partial partitioning contactor and in the scrub section of the $1 \mathrm{D}$ contactor of the second uranium cycle, these changes have not been tested at this time. Substitution of a cation-exchange column for the third-cycle solvent extraction might yield the required decontamination factor, such a column would slowly accumulate plutonium that would have to be returned to an earlier cycle. This much pure plutonium may not be acceptable. 


\section{Partial-Partitioning}

The preferred method of operating the B contactor to achieve partial partioning is shown in Figure 3 . It differs from the usual Purex $B$ contactor in two main respects.

1) The scrub section has been eliminated by moving the feed point from the center of the bank to the end. This change ensures that some uranium will remain in the aqueous phase, and a pure plutonium product will be almost impossible to get. The amount of uranium that is stripped with the plutonium can be controlled by varying the different process parameters (concentrations, flow rates, etc.).

2) A reductant is needed to ensure complete stripping of the plutonium. Hydroxylamine nitrate (HAN) is used as the plutonium reductant instead of ferrous sulfamate. Ferrous sulfamate is an effective plutonium reductant; but the iron contributes to the waste volume, and sulfamate is converted to sulfate which is undesirable in the waste handling process.

HAN as reductant is an attractive alternative in several respects: 1) it is converted to gaseous products and water, both of which do not contribute to waste. 2) HAN becomes less effective as the acidity increases. Therefore, an upper limit to the plutonium content in the uranium-plutonium product can be achieved by simply increasing the acidity. 3) HAN is readily destroyed by NO or by heating in $\mathrm{HNO}_{3}$ to allow plutonium valence adjustment before the second and third uranium-plutonium cycles.

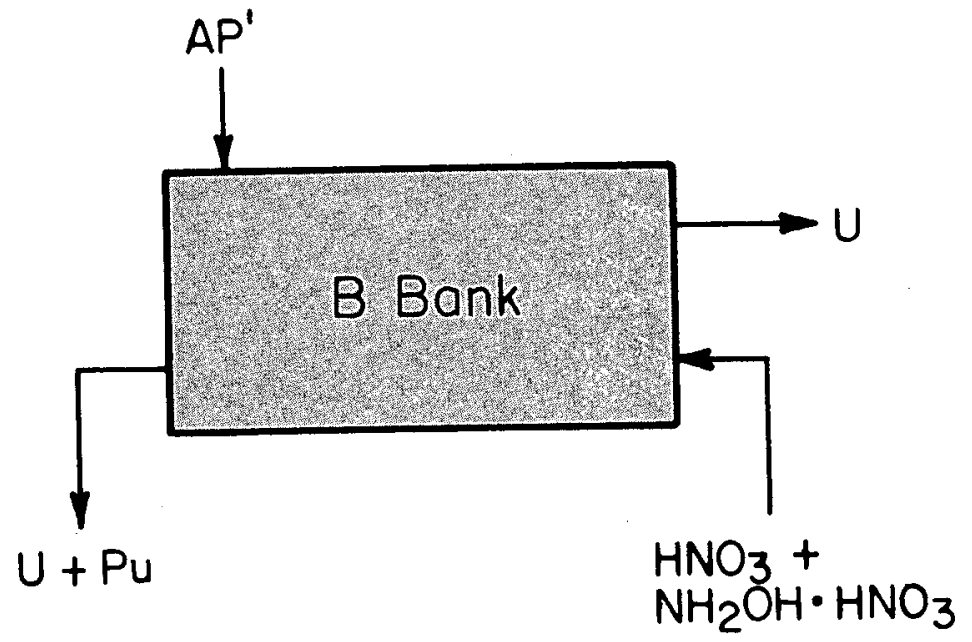

FIGURE 3. Partial Partitioning with Hydroxylamine Nitrate 
The coprocessing flowsheet has one major advantage over that in the normal Purex process: the elimination of the scrub section. The elimination of the scrub step reduces the possibility of plutonium reoxidation by nitrite. Therefore, less reductant can be used; and a holding reductant for the plutonium, such as hydrazine, is not necessary. When hydrazine is absent, the need to consider handling hydrazoic acid or azides is eliminated.

Three other modes of B contactor operation for partial partitioning were considered (Figure 4).

Figure 4a shows B contactor operation with U(IV) reductant. U(IV) strips plutonium better than other reductants because U(IV) can replace any $\mathrm{Pu}(\mathrm{IV})$ complexed by dibutyl phosphate. ${ }^{1}$ Like hydroxylamine, U(IV) does not increase waste volumes but does require stabilization with hydrazine. Reduction with $U(I V)$ is less dependent upon acidity than reduction with hydroxylamine, therefore reduction with U(IV) could yield a product with a higher plutonium content.

U(IV) could be produced electrolytically from a portion of the uranium product stream (1CU or 2 EU, Figure 1). However, recycling uranium would complicate accountability, because either uranium must be added; or an inventory of uranium must be maintained. Furthermore, operation with U(IV) would require more feed streams to the contactor, complicating operation.

Figure 4b shows B contactor operation with uranium saturation and hydroxylamine nitrate reductant. Uranium is recycled from the $1 C U$ (or 2EU) stream to saturate the organic phase and reduce the $\mathrm{Pu}$ (IV) distribution coefficient, so that $\mathrm{Pu}(\mathrm{IV})$ is stripped without reduction. A low concentration of hydroxylamine nitrate reduces any residual $\mathrm{Pu}(\mathrm{IV})$ to $\mathrm{Pu}(\mathrm{III})$, to complete the stripping of plutonium. This mode of operation ensures uranium in the plutonium and reduces added chemicals. However, computer calculations show that the product contains too little plutonium (no more than $2 \%$ ) for recycling as reactor fuel.

Figure $4 \mathrm{c}$ shows $\mathrm{B}$ contactor operation with uranium saturation but no reductant. This variation of the previous mode allows better control of plutonium and uranium in the product. However, Rosen and Zel'venskii ${ }^{2}$ evaluated this type of operation for complete partitioning of uranium and plutonium and concluded that control would be difficult because small changes in solution flows or concentrations cause large changes in product concentrations. Calculations at SRL reveal the same problem when the process is modified to yield a uranium-plutonium stream. These results are expected because operation at saturation means operation in a metastable state, where small changes in conditions can cause large changes in product concentrations. 


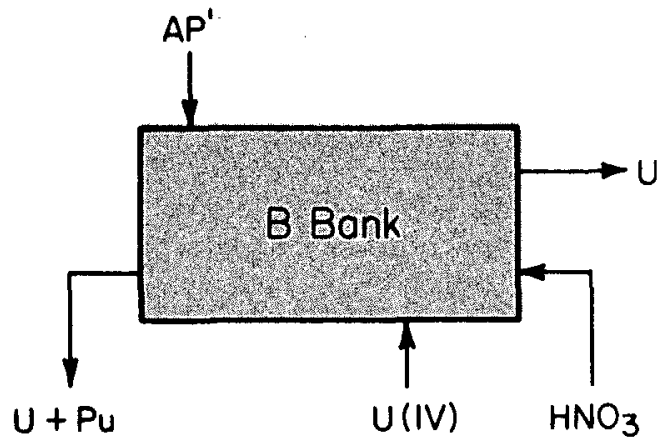

a. Partial Partitioning with Uranium (IV)

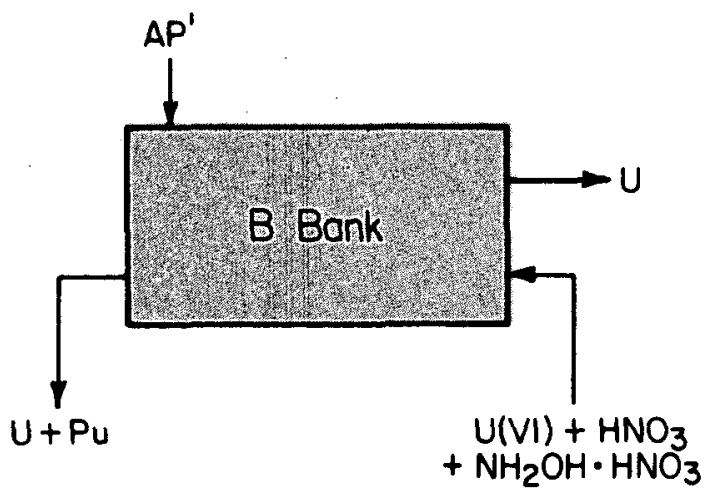

b. Partial Partitioning with Uranium Saturation and Hydroxylamine Nitrate

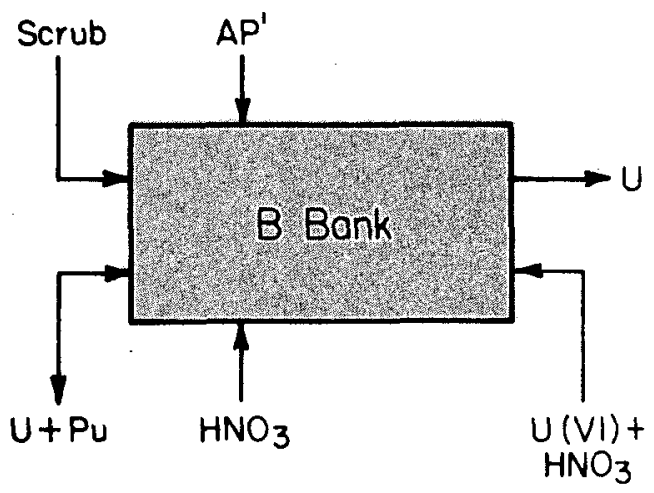

c. Portiol Portitioning with Uronium Saturation but no Reductont

FIGURE 4. Alternative Operational Modes for Coprocessing Uranium and Plutonium in B Contactor 


\section{Feasibility}

Leaving some uranium with the plutonium would not be a drastic change from normal Purex operation. In fact, obtaining a pure plutonium stream is harder than leaving some uranium with plutonium. The difficulty with coprocessing is precisely controlling the uranium concentration in the uranium-plutonium product to obtain a desired reactivity for fuel fabrication and reirradiation. This difficulty could be overcome by obtaining the product at a somewhat higher plutonium concentration than desired for fuel fabrication and by diluting the plutonium with uranium to the precise concentration desired.

Coprocessing is technically feasible for any mixture of uranium and plutonium, so the concentration of plutonium must be specified before a process can be designed. The upper limit of the concentration of plutonium will be determined by the requirement that the concentration of plutonium be too low for direct use in a nuclear weapon. This limit is presumed to be $11.7 \%$ plutonium in uranium + plutonium, because $11.7 \%$ tota $1 \mathrm{Pu}\left(60 \%{ }^{239} \mathrm{Pu}, 25 \%\right.$ ${ }^{240} \mathrm{Pu}, 15 \%{ }^{241} \mathrm{Pu}$ ) in natural uranium has been calculated to have the same reactivity as uranium enriched to $20 \%{ }^{235} \mathrm{U}$. Twenty percent is the highest enrichment that DOE allows to be shipped without safeguards restrictions. ${ }^{3}$ The lower limit will be about $5 \%$, the concentration of plutonium necessary to make mixed-oxide (MOX) fuel for power reactors.

\section{COMPUTER STUDIES}

The effects of the different process variables for the most promising B contactor operating mode (Figure 3 ) were calculated with a modification of the SEPHIS program. ${ }^{4}$ This program, which is based upon the distribution coefficients of $\mathrm{UO}_{2}^{2+}, \mathrm{Pu}^{4+}$, and $\mathrm{HNO}_{3}$ gives an indication of those results that depend upon flow rates, concentrations, and temperature. However, the program does not allow for chemical reactions or the rate of $\mathrm{Pu}$ (IV) reduction. $\mathrm{Pu}(\mathrm{IV})$ reduction is simulated by entering a negative plutonium term and calculated as instantaneous and irreversible. Therefore, SEPHIS cannot predict the effect of different reductant concentrations; as far as SEPHIS is concerned, the main effect of hydroxy1amine nitrate is to add inextractable nitrate.

Computer results were evaluated in terms of the increase in the amount of plutonium as a fraction of the total heavy metal (uranium + plutonium) concentration in the product stream relative to the feed. The increase in plutonium was calculated for the $B$ contactor only, assuming a constant feed from the A or A' contactor. Since the amount of plutonium in the feed will vary with different fuels, the relative increase in plutonium is more informative than 
the absolute value of the final concentration. A concentration factor (CF) was defined as

$$
\mathrm{CF}=\frac{\% \mathrm{Pu} \text { in Total Heavy Metal in Product }}{\% \mathrm{Pu} \text { in Total Heavy Metal in Feed }}
$$

Based upon the initial plutonium concentration, the concentration factor can be chosen to yield the desired product composition.

The importance of ten process variables in controlling the concentration factor was evaluated by a Plackett-Burman statistical screening design (Appendix A). ${ }^{5}$ An effect was calculated for each variable. The magnitude of each effect indicates the relative importance of the corresponding variable; those with effects greater than the minimum significant effect are statistically significant in determining the concentration factor. The sign of the effect indicates whether the concentration factor increases or decreases as that variable increases.

Although there is no experimental error with computer calculations, the system is very complex. With a twenty-run design, the variation in concentration factor with random arrangements of the variables was very high. This variation was decreased considerably by using a 40-run design.

Variables tested included flow rates, concentrations, temperature, and number of stages. Ranges were chosen to reflect reasonable operating conditions. Variables are ranked in Table 1 according to the magnitude of their effects on the concentration factor. The three most important variables are inextractable nitrate concentration, $\%$ TBP in the organic feed (BF) to the $B$ contactor from the $A$ or $A^{\prime}$ contactor, and the aqueous extractant (BX) (hydroxylamine nitrate + nitric acid) flow rate. Uranium concentration in the $\mathrm{BF}$ stream, the $\mathrm{BF}$ flow rate, and temperature are also important. Plutonium concentration and acidity of the BF stream, acidity of the BX stream and the number of mixersettler stages are without significant effect.

In practice, the $\%$ TBP, temperature, and probably the uranium concentration will be held constant. The concentration factor will then be controlled by varying the flow rates and the nitrate concentration in the $B X$ stream. The flow ratio and nitrate concentration necessary to yield the desired concentration factor can be determined from plots such as Figure 5.

Although the acidity of the $\mathrm{BX}$ and $\mathrm{BF}$, the plutonium content, and the number of stages are not statistically significant, they may still have some effect because of interactions with other variables. Additional calculations holding the other parameters constant at an intermediate level show that the concentration 
factor increases slightly with increasing acidity and decreases with increasing plutonium concentration. However, as expected, the changes are small.

The $\mathrm{BX}$ acid concentration is least important, but its range is limited by other considerations. The acidity must not be less than $0.1 \mathrm{M}$, to avoid formation of plutonium hydroxide polymer. ${ }^{6}$ Once formed, the polymer is very stable and would result in large plutonium losses during further processing. The diminished sta-. bility of hydroxylamine and the slower rate of $\mathrm{Pu}$ (IV) reduction at high acidity sets an upper limit on the concentration of nitric acid in the $\mathrm{BX}$ stream. The rate of reduction of $\mathrm{Pu}(\mathrm{IV})$ by hydroxylamine depends upon $1 /[\mathrm{H}+]^{4}$ (Reference 7 ) so that the acidity will have a marked effect.

\section{TABLE 1}

Effect of Process Variables in B Mixer-Settler

Variable

Significant

Nitrate in $B X$

$\mathrm{TBP}$ in $\mathrm{BF}$

BX Flow Rate

Uranium in $\mathrm{BF}$

BF Flow Rate

Temperature

Not Significant ${ }^{a}$ Range Effect

$$
\text { Plutonium in BF }
$$$$
0.4 \text { to } 1.0 \mathrm{~g} / \mathrm{L}
$$

Acidity of $\mathrm{BF}$

0.04 to $0.15 \mathrm{M}$

$+3.7$

Number of Stages

12 to 20

$-2.1$

Acidity of $\mathrm{BX}$

0.2 to $0.75 \mathrm{M}$

$+1.0$

a. Minimum significant effect $=+4.5$. 


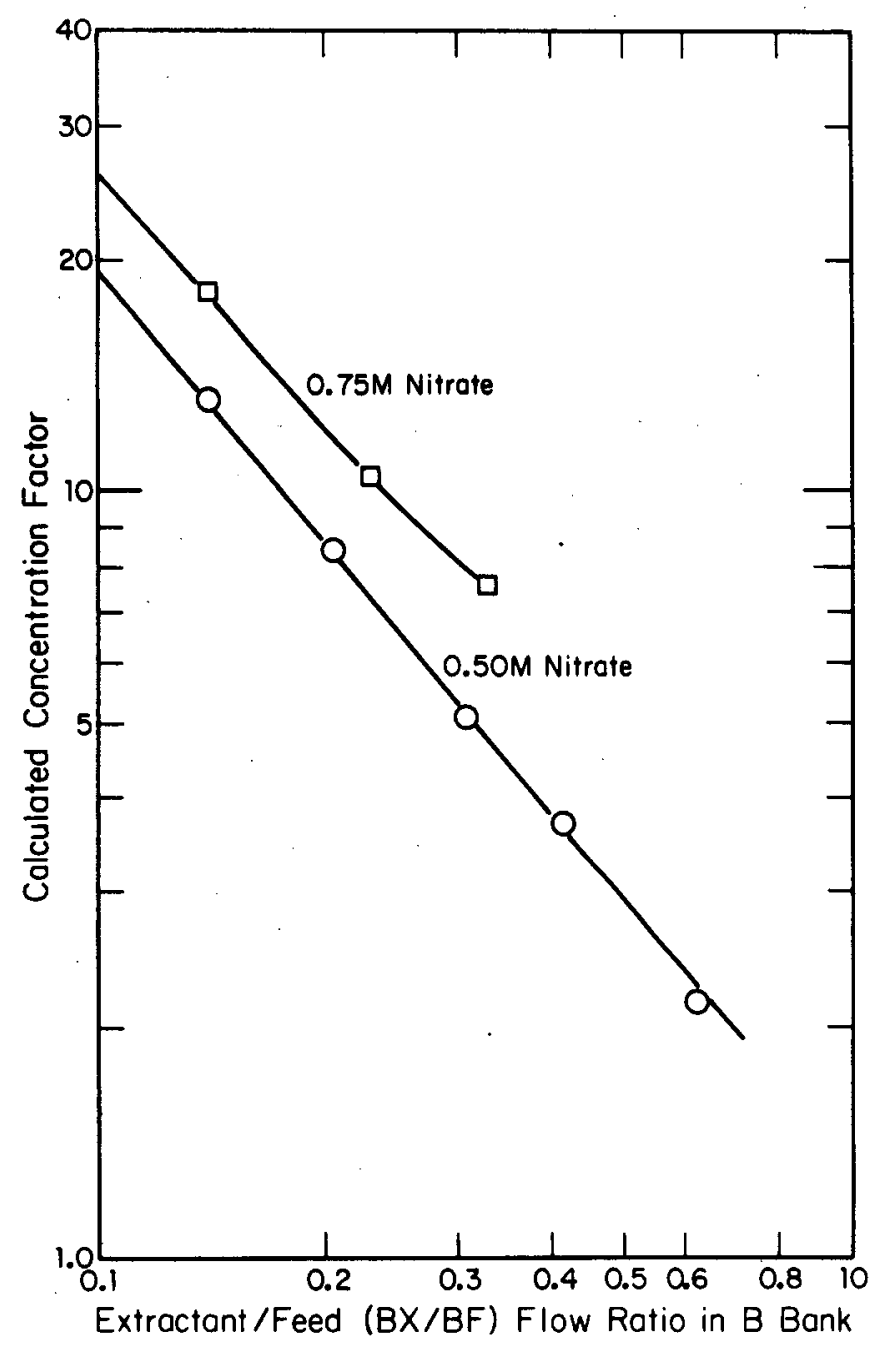

FIGURE 5. Plutonium Concentration Factors Calculated by SEPHIS

\section{MIXER-SETTLER TESTS}

\section{Simulated Feed}

Mixer-settler tests with simulated feed demonstrated plutonium concentration factors from 6 to 27.4. The B mixer settler-operated effectively with less than $0.03 \%$ loss of plutonium to the BU stream. The conditions derived from SEPHIS calculations were adequate for predicting the concentration factors for these tests.

Conditions for a range of plutonium concentration factors were calculated by SEPHIS. The actual concentration factor which is needed to yield a given plutonium/uranium ratio in the product will vary with the initial plutonium concentration. The availability of a range of concentration factors will allow coprocessing of fuel of any composition to the desired plutonium/uranium ratio. 
Three tests were run in the miniature mixer-settlers, with target concentration factors of 5,13 , and 26 . The same feed was used in all tests (Table 2). The plutonium content was $0.9 \%$ of the total heavy metal content, typical of LWR fuel with burnup of $30,000 \mathrm{MWD} / \mathrm{T}$. Before each test, the feed was sparged with air to remove $\mathrm{NO}_{\mathrm{x}}$ species and reduce possible reoxidation of plutonium by nitrite. The tests were run for 10 to 12 hours for two consecutive days. Test conditions are summarized in Tables 2 and 3 .

\section{TABLE 2}

A Mixer-Settler Operating Conditions for All Tests With Simulated Feed

$\begin{array}{llll}\text { Stream } & \text { Composition } & \text { Stage } & \begin{array}{l}\text { Flow, } \\ \mathrm{mL} / \mathrm{min}\end{array} \\ \mathrm{CAF} & 250 \mathrm{~g} / \mathrm{L} \mathrm{U} & 8 & 0.75 \\ & 2.3 \mathrm{M} \mathrm{HNO} & & \\ \mathrm{HAF} & 250 \mathrm{~g} / \mathrm{L} \mathrm{U} & 8 & 0.75 \\ & 2.3 \mathrm{~g} / \mathrm{L} \mathrm{Pu} & & \\ & 2.3 \mathrm{M} \mathrm{HNO} & & \\ \mathrm{AX} & 30 \% \mathrm{TBP}_{3} & 16 & 2.14 \\ \mathrm{AS} & 1.0 \mathrm{M} \mathrm{HNO}_{3} & 1 & 0.40\end{array}$

\section{TABLE 3}

B Mixer-Settler Operating Conditions for Tests With Simulated Feed

\begin{tabular}{|c|c|c|c|c|}
\hline & BX Composi & $n_{2} M$ & $B X$ Flow, & \\
\hline Test & $\mathrm{NH}_{2} \mathrm{OH} \cdot \mathrm{HNO}_{3}$ & $\mathrm{HNO}_{3}$ & $m L / m i n$ & $H A N / P u$ \\
\hline SIM-1 & 0.50 & 0.20 & 0.65 & 45 \\
\hline SIM-2 & 0.50 & 0.20 & 0.30 & 21 \\
\hline SIM-3 & 0.75 & 0.15 & 0.21 & 21 \\
\hline
\end{tabular}


A mixer-settler conditions were identical for the three tests. Analysis of the AP product stream indicated effective A mixersettler operation; uranium, plutonium, and acid concentrations were very close to those predicted by SEPHIS calculations. Feed compositions used to calculate B mixer-settler conditions were therefore very close to actual conditions. Losses to the AW waste stream were low, although slightly higher than design values. Because the objective of the tests was to evaluate B mixer settler operation, A mixer-settler conditions were not adjusted.

In all three tests, a large excess of hydroxylamine nitrate was used. This amount of reductant was not necessary to ensure complete reduction of plutonium in this flowsheet. There is no scrub section, and reoxidation of plutonium should not be as serious a problem as in the usual Purex process. However, because hydroxylamine nitrate also serves as a source of inextractable nitrate, its concentration is critical. To obtain concentration factors of 5 to 25, the concentration of inextractable nitrate should range from 0.5 to $0.75 \mathrm{M}$, which corresponds to a 20 - to 45 fold excess of hydroxylamine nitrate, depending upon the flow rates. Therefore, the amount of hydroxylamine nitrate was determined primarily by the need for nitrate salt rather than for reductant.

In all three tests, equilibrium was reached within about six hours; and after that, the mixer-settlers were stable. The plutonium concentration in the plutonium (BP) and uranium (BU) product streams leveled off (Figure 6). Analyses showed that the BP accounted for 95 to $99 \%$ of the plutonium in the feed. Allowing for dilution effects and experimental error, all plutonium was recovered in the $B P$.

Plutonium losses to the BU did not exceed $0.03 \%$ (Table 4). Because the activity of the BU is very low, $1-5 \times 10^{4} \mathrm{dis} /(\mathrm{min}-\mathrm{mL})$, there is a substantial contribution from the uranium. This contribution means that the real plutonium concentration (and $\% \mathrm{Pu}$ loss) is probably much lower than that calculated from the gross alpha data. Therefore, the values reported for $\% \mathrm{Pu}$ loss to the BU will represent an upper limit.

Because of the low plutonium losses to the BU, the plutonium decontamination factors for the uranium stream were high (Table 4). However, this degree of decontamination would be insufficient to allow coprocessing by the flowsheet shown in Figure 2 if an overall decontamination factor of $2-4 \times 10^{8}$ is required. Achievement of an overall decontamination factor of $2-4 \times 10^{8}$ would probably require two additional uranium-purification cycles. Consequently, the better choice is still the flowsheet shown in Figure 1, with a modified $1 \mathrm{~B}$ mixer-settler. 


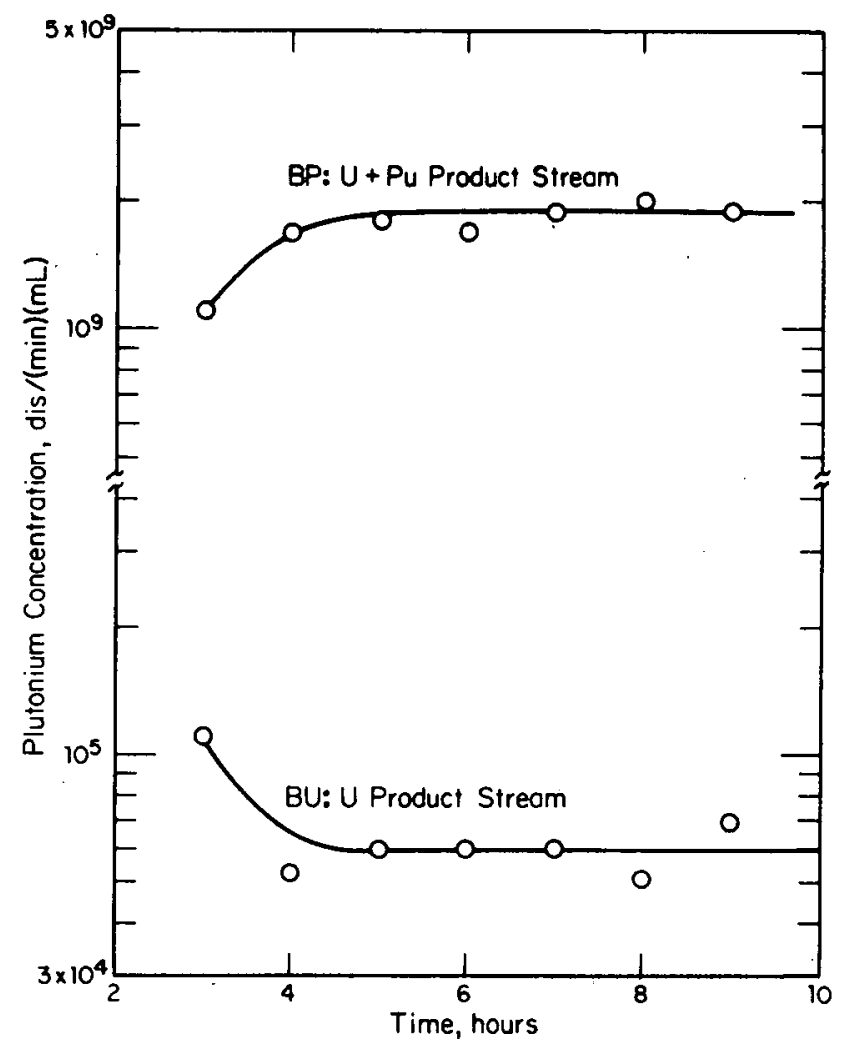

FIGURE 6. Observed Equilibration of Plutonium in B Mixer-Settler Product Streams

TABLE 4

Results of Tests With Simulated Feed

Test \% Pu Loss to BU \% Pu(U+PU) in BP DF

SIM- $1<0.02$

5.8

$4 \times 10^{3}$

SIM-2 $<0.03$

16.0

$5 \times 10^{3}$

SIM-3 $<0.03$

25.0

$3 \times 10^{3}$ 
Irradiated LWR Fuel

Mixer-settler tests with irradiated LWR fuel showed effective partial-partitioning. The plutonium losses to the BU were less than $0.02 \%$. In addition, the effect of high acid in the BX was shown.

Three hot cell tests were run in miniature mixer-settlers with fuel from the Oconee-1 reactor. The feed compositions and run conditions are summarized in Tables 5 and 6 . The tests were run for 8 to 10 continuous hours. The feed was not air-sparged before running.

TABLE 5

Oconee-1 Feed Composition

$\begin{array}{llll}\text { Test } & U, g / L & \text { Pu, g/L } & H^{+}, M \\ \text { LWR-1 } & 285 & 1.6 & 2.5 \\ \text { LWR-2 } & 257 & 1.5 & 2.5 \\ \text { LWR-3 } & 330 & 1.9 & 2.5\end{array}$

TABLE 6

B Mixer-Settler Operating Conditions for Tests With Oconee-1 Fuel

\begin{tabular}{|c|c|c|c|c|c|}
\hline \multirow[b]{2}{*}{ Test } & \multicolumn{2}{|c|}{ BX Composition, $M$} & \multicolumn{2}{|c|}{ Flow Rate, $\mathrm{mL} / \mathrm{min}$} & \multirow[b]{2}{*}{$H A N / P u$} \\
\hline & $\mathrm{NH}_{2} \mathrm{OH} \cdot \mathrm{HNO}_{3}$ & $\mathrm{HNO}_{3}$ & $\overline{B X}$ & $B F$ & \\
\hline LWR-1 & 0.50 & 1.0 & 0.30 & 3.02 & 32 \\
\hline LWR - 2 & 0.50 & 0.3 & 0.65 & 3.02 & 70 \\
\hline LWR-3 & 0.80 & 0.5 & 0.45 & 3.63 & 40 \\
\hline
\end{tabular}


In the first test, the $B$ mixer-settler did not partition effectively; and the plutonium losses to the BU product stream were high (Table 7). Since the initial plutonium concentration was $0.56 \%$, a concentration factor of 36 was required to achieve a plutonium concentration of $20 \%$ of the heavy metal content in the BP. A high acid concentration was used to reduce the quantity of uranium stripped into the BP. Under these conditions, HAN did not effectively reduce the plutonium. Thus, high losses to the uranium product resulted.

\begin{tabular}{|c|c|c|}
\hline \multicolumn{3}{|c|}{ Results of Tests With Oconee-1 Fuel } \\
\hline Test & $\%$. Pu Loss to $B U$ & $\%$ Pu $(U+P u)$ in $B P$ \\
\hline LWR-1 & 27.2 & - \\
\hline LWR-2 & 0.015 & 10.2 \\
\hline LWR- 3 & 0.009 & 12.5 \\
\hline
\end{tabular}

The plutonium concentration in the BP leveled off after about 6 hours. However, plutonium losses to the BU increased steadily to a maximum of $27 \%$ at the end of the test (Table 8 ). Almost $100 \%$ of the total plutonium in the feed was appearing in the BP and BU streams, indicating that equilibrium had probably been reached. The B mixer-settler plutonium profile on this test is compared with that of simulated Test 2. See Table 4 and Figure 7 . From Figure 7 , it can be seen that the plutonium was not being stripped into the aqueous phase in this first test.

The high plutonium losses cannot be explained by reoxidation of $\mathrm{Pu}(\mathrm{III})$. The reducing normality of the BP indicated that $60 \%$ of the $\mathrm{NH}_{2} \mathrm{OH} \cdot \mathrm{HNO}_{3}$ was still present, which should have been sufficient to prevent reoxidation of Pu(III). However, the acid concentration in the aqueous phase of the latter $B$ mixer-settler stages was 1.6 to $1.7 \mathrm{M}$; at this acidity, reduction is much slower and only part of the plutonium may have been reduced. These conditions then represent an upper limit for the acid concentration in the $B X$ if hydroxylamine nitrate is the reductant.

In second and third tests, the acidity of the aqueous strip was lowered; and excellent separation was achieved (Table 7). 
TABLE 8

Plutonium Content of the BP and BU Product Streams During the LWR-1 Test

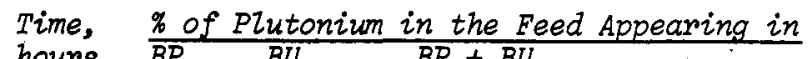

$\begin{array}{llll}4 & 52.2 & 1.1 & 53.3 \\ 5 & 58.9 & 7.0 & 65.9 \\ 6 & 64.4 & 12.4 & 76.8 \\ 7 & 64.4 & 11.5 & 75.9 \\ 8 & 69.3 & 14.8 & 84.1 \\ 9 & 69.3 & 27.2 & 96.5\end{array}$

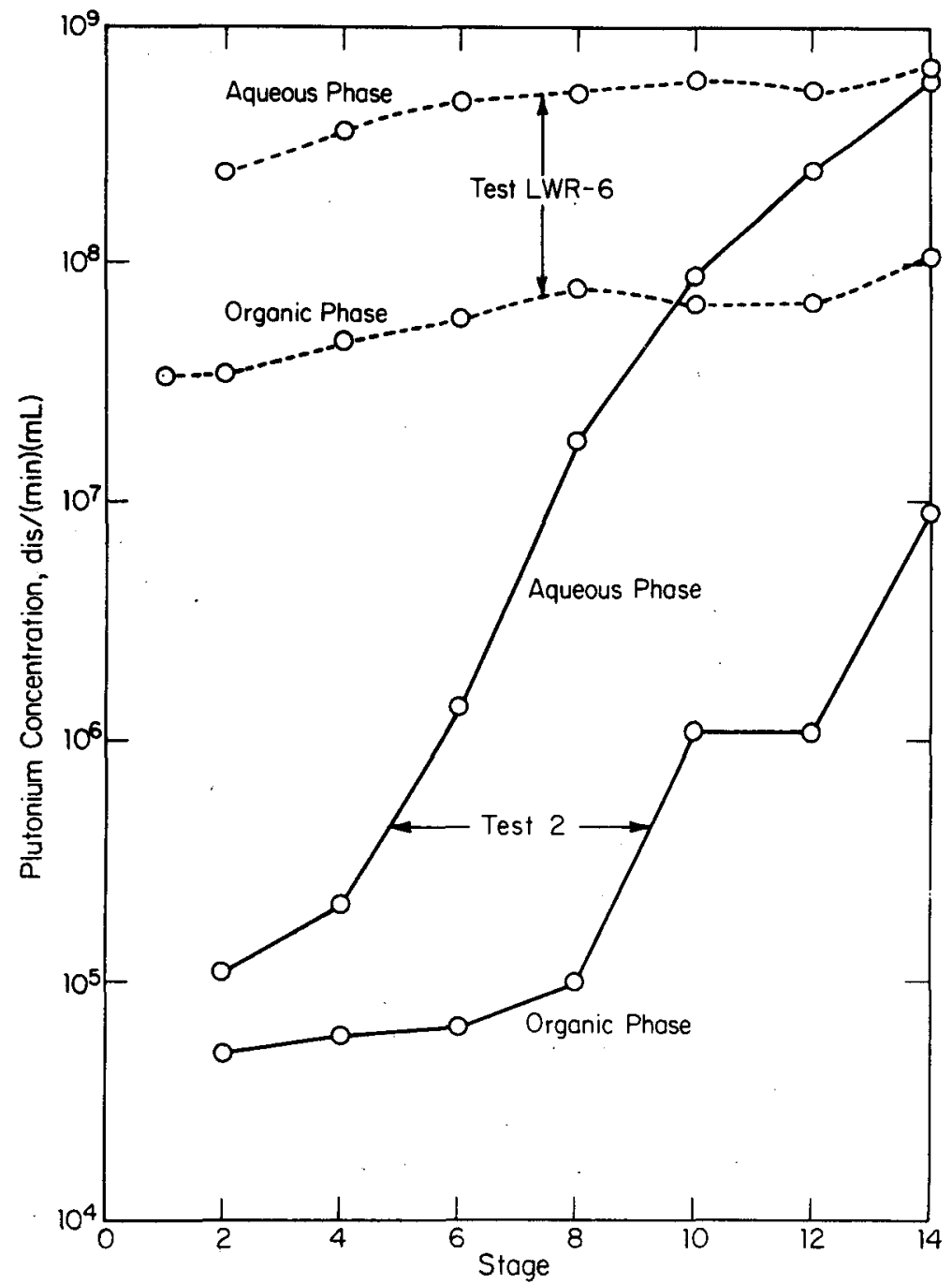

FIGURE 7. Plutonium Profiles in B Mixer-Settler During Test LWR- 1 and Simulated Test 2 
The plutonium impurity in the uranium product was well below the design limit of $0.05 \%$ and much better than the $0.12 \%$ achieved in total partitioning studies. ${ }^{8}$ This improvement in plutonium decontamination in partial partitioning is probably due to the increase in the number of stripping stages (16 versus 8 in total partitioning) and to the elimination of the scrub section which reduces plutonium reoxidation and re-extraction. The results from the last two cell tests agree with those from tests with simulated feed which indicated that HAN could be used without hydrazine in partial partitioning.

The excess $\mathrm{NH}_{2} \mathrm{OH} \cdot \mathrm{HNO}_{3}$ was greater in the second test than in the first test, but the greater excess was not the cause of the improved separation in the second test. In tests with simulated feed, the $\mathrm{NH}_{2} \mathrm{OH} \cdot \mathrm{HNO}_{3}$-to-plutonium ratio, which varied from 21 to 45, had little effect on the level of plutonium impurity in the uranium product. As long as $\mathrm{NH}_{2} \mathrm{OH} \cdot \mathrm{HNO}_{3}$ is sufficient to reduce al1 the plutonium, and the rate of reduction is fast enough to be complete within the residence time of the contactor, the increase of the $\mathrm{NH}_{2} \mathrm{OH} \cdot \mathrm{HNO}_{3}$-to-plutonium ratio is expected to have little effect on the plutonium decontamination of the uranium product. For tota? partitioning in mixer-settlers, other investigators indicate that the ratio of $\mathrm{NH}_{2} \mathrm{OH} \cdot \mathrm{HNO}_{3}$ to plutonium in product should not exceed three; ${ }^{9}$ above that ratio, the rate of reduction decreases with the increase of $\mathrm{NH}_{2} \mathrm{OH} \cdot \mathrm{HNO}_{3}$. However, in the present partial-partitioning tests, where the ratio was as high as 70 , slower reduction rates as a factor were not evident.

\section{Comparison of Test Results with SEPHIS Calculations}

Overall, the SEPHIS calculations of the concentration factors were within about $20 \%$ of the observed concentration factors (Table 9). Therefore, the calculations are useful as a first approximation of the conditions needed to produce a given concentration factor, but exact conditions must be determined by experiment. The differences between observed and calculated concentration factors are due to slight deviations in actual test conditions from those specified for the calculations, and to the failure of the calculational model to closely simulate the real system.

The measured concentration factors for the tests with simulated feed and for the second cell test were higher than predicted. The two test factors in which deviations are most likely to have caused the differences in the concentration factor here are the TBP concentration and the $\mathrm{BX}$ flow rate. The TBP concentration actually used was high $(31 \%)$. Because the $\%$ TBP has a large positive effect on the concentration factor (Table 1), observed concentration factors would be expected to be higher than calculated. 
TABLE 9

Calculated and Observed Concentration Factors

\begin{tabular}{llll} 
& \multicolumn{2}{l}{ Concentration Factor } & $\%\left(\frac{\text { Obs-Calc }}{\text { Obs }}\right)$ \\
\cline { 2 - 4 } Observed & Calculated & \\
SIM-1 & 6.4 & 5.2 & 19 \\
SIM-2 & 17.6 & 13.0 & 26 \\
SIM-3 & 27.4 & 26.1 & 5 \\
LWR-2 & 17.6 & 14.0 & 21 \\
LWR-3 & 21.5 & 25.5 & 18
\end{tabular}

Table 1 shows that the concentration factor is also sensitive to the $B X$ flow rate. Figure 8 shows slight changes in flow rate cause significant changes in the concentration factor at low flow rates. For the tests with simulated feed, this effect is greater for Tests 2 and 3 than for Test 1 . However, the difference between calculated and observed concentration factors is less for Tést 3 than for Test 2, despite the lower BX flow rate for Test 3 (steeper part of the curve). An additional factor in Test 2 was the large variation in BP uranium content; the uranium concentration in samples taken after equilibrium had been reached varied as much as $13 \%$ whereas the variation was less than $5 \%$ for Tests 1 and 3 . This trend agrees with SEPHIS calculations, which indicated that the uranium variability would be higher at low nitrate concentrations and high concentration factors, as in Test 2 .

In the third cell test, the observed concentration factor was less than that predicted by SEPHIS calculations. Just before the third cell test, new mixer-settlers were installed; the new equipment probably accounted for the change. The old equipment probably had lower efficiency than the new mixer-settlers. The lower efficiency would mean that the true equilibrium uranium distribution would not be reached in the latter stages of the B mixersettler. The lower efficiency would result in less uranium being stripped into the aqueous phase which would give high concentration factor values. The improved efficiency of the new mixersettlers would result in more uranium being stripped, and the concentration factor values would be lower than expected, based upon the previous experiments. 


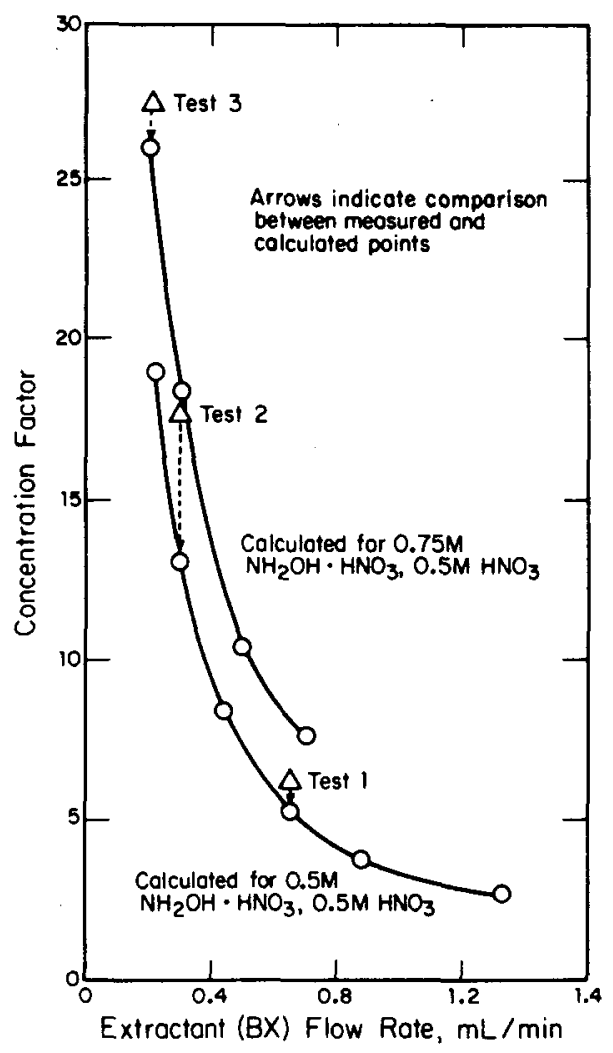

FIGURE 8. Effect of Extractant Flow Rate on Plutonium Concentration Factor in B Mixer-Settler

Although SEPHIS predicts concentration factors reasonably well, it does not predict uranium and acid concentration profiles in the bank. (The SEPHIS plutonium profile is meaningless because of the artificial way in which plutonium reduction is treated.) Therefore, the program cannot be relied upon to simulate the real system.

\section{Stoichiometry Tests}

Mixer-settler tests made with simulated feed showed that a molar ratio $\mathrm{HAN} / \mathrm{Pu}$ as $10 \mathrm{w}$ as $2.8 / 1$ is sufficient to ensure that plutonium is completely reduced in the absence of nitrite. The stoichiometry of the reduction of plutonium by HAN is intermediate, between a Pu/HAN ratio of $1 / 1$ and $2 / 1$, but closer to $2 / 1$.

Three tests were made under identical conditions except for the BX composition (Table 10). The HAN concentration in the BX was varied to achieve $\mathrm{HAN} / \mathrm{Pu}$ ratios of $13 / 1,7.4 / 1$, and $2.8 / 1$. The total $\mathrm{BX}$ nitrate concentration was held constant at $0.5 \mathrm{M}$ by the addition of $\mathrm{NH}_{4} \mathrm{NO}_{3}$. The feed was air-sparged before the test to eliminate nitrite. 
TABLE 10

Operating Conditions for Stoichiometry Tests

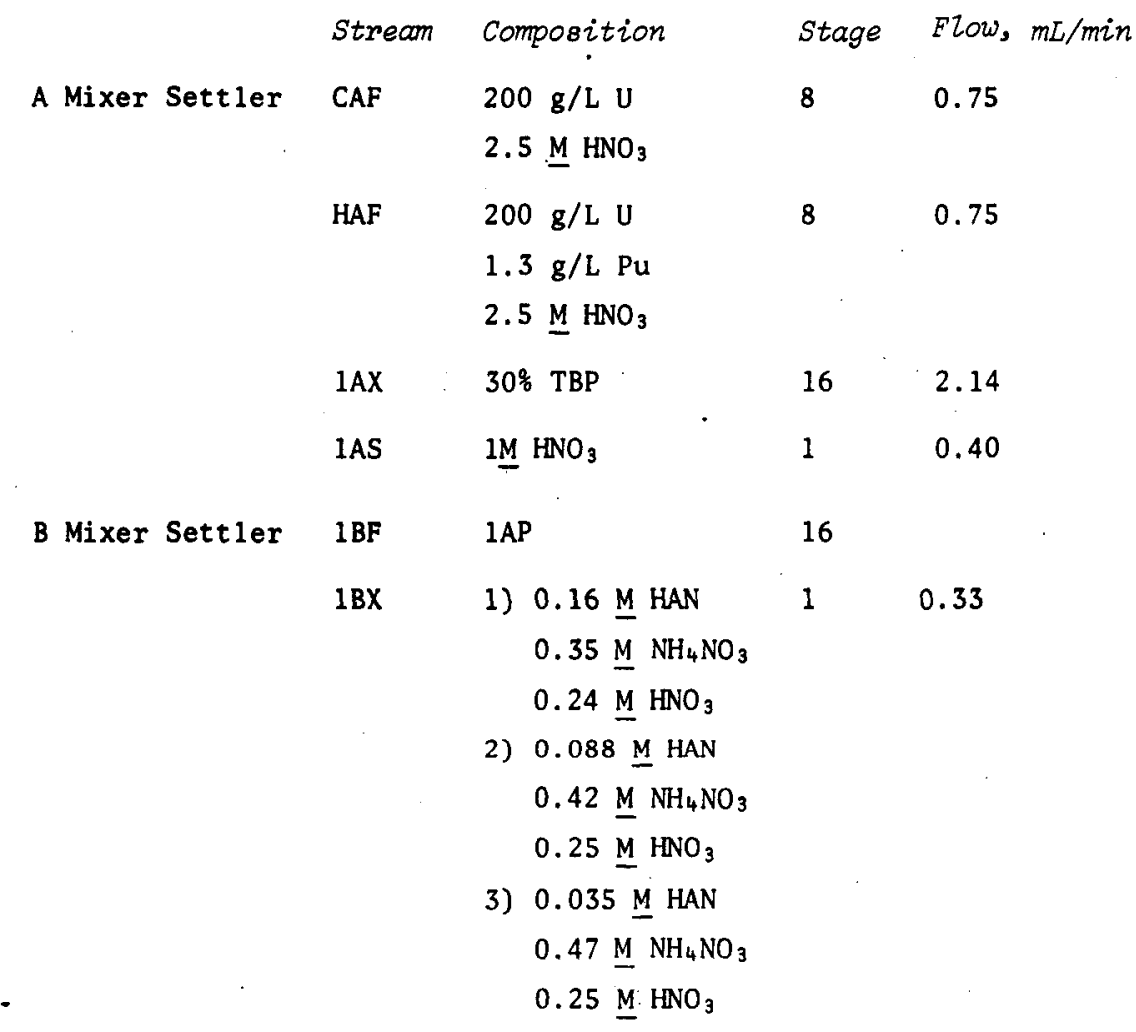

In all three tests, partial partitioning was effective; and plutonium losses to the BU were at the background level $(<0.03 \%)$. The plutonium distribution across the $B$ mixer-settler was the same for all three tests as shown in Figure 9 for the organic phase. The aqueous phase distribution of plutonium for Stoichiometry Test 3 is similar to that of Simulated Test 2 in which a 21-fold excess of HAN was used (Figure 10). The curve for Stoichiometry Test 3 is lower, in part because of the lower plutonium concentration in the feed. In addition, the stoichiometry test was run with the new mixer-settlers, and the improved efficiency might cause the plutonium level to drop off more sharply.

The stoichiometry of the reaction was intermediate between one and two moles of $\mathrm{Pu}(\mathrm{IV}$ ) reduced per mole of HAN (Table 11). Both Reactions 1 and 2 must be taking place:

$$
\begin{aligned}
& 2 \mathrm{NH}_{3} \mathrm{OH}^{+}+2 \mathrm{Pu}^{+4} \rightarrow 2 \mathrm{Pu}^{+}+\mathrm{N}_{2}+2 \mathrm{H}_{2} \mathrm{O}+4 \mathrm{H}^{+} \\
& 2 \mathrm{NH}_{3} \mathrm{OH}^{+}+4 \mathrm{Pu}^{+} \rightarrow 4 \mathrm{Pu}^{+}+\mathrm{N}_{2} \mathrm{O}+\mathrm{H}_{2} \mathrm{O}+6 \mathrm{H}^{+} .
\end{aligned}
$$




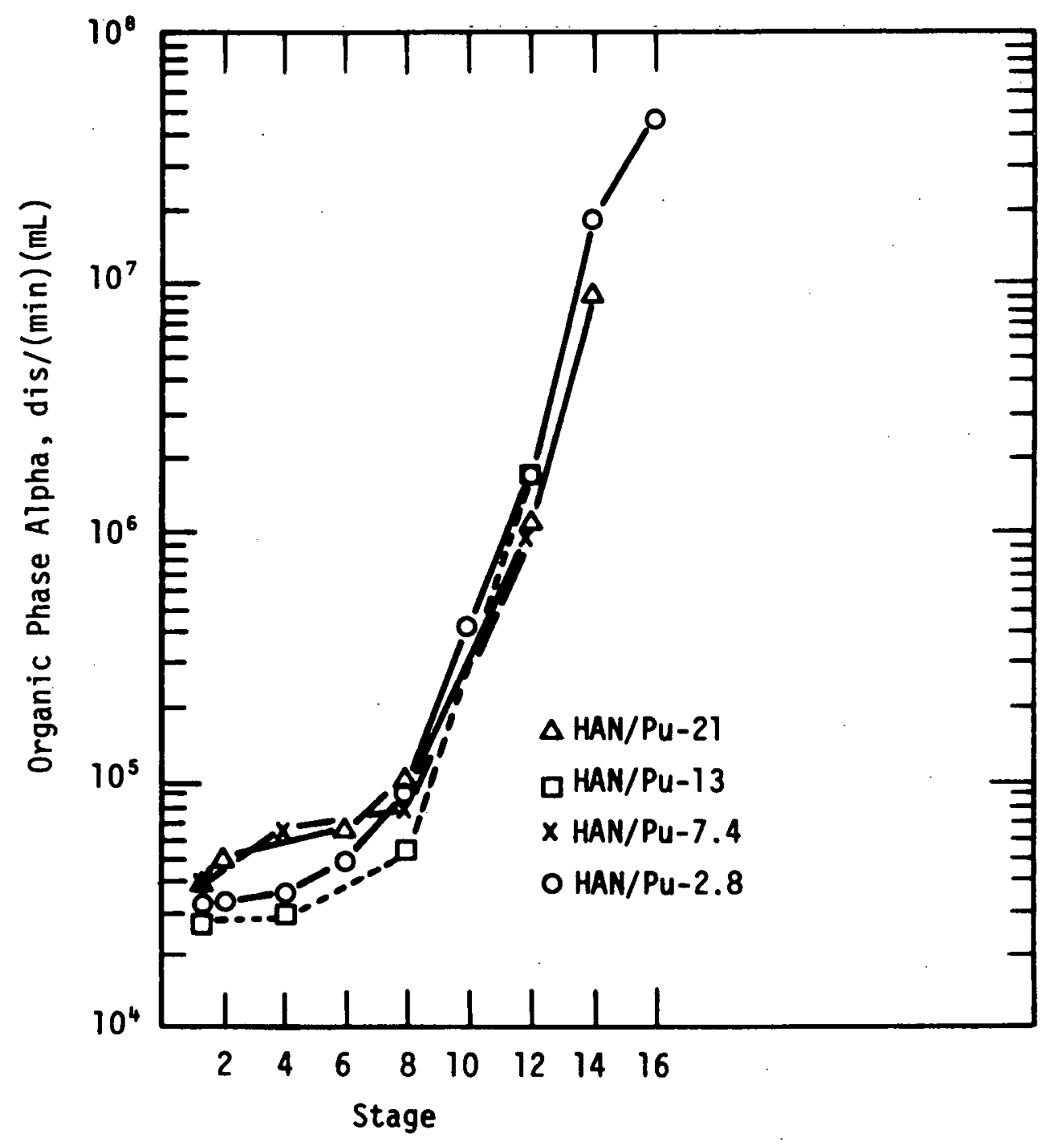

FIGURE 9. Organic Plutonium Profiles in B Mixer-Settler at Different HAN/Pu Ratios 


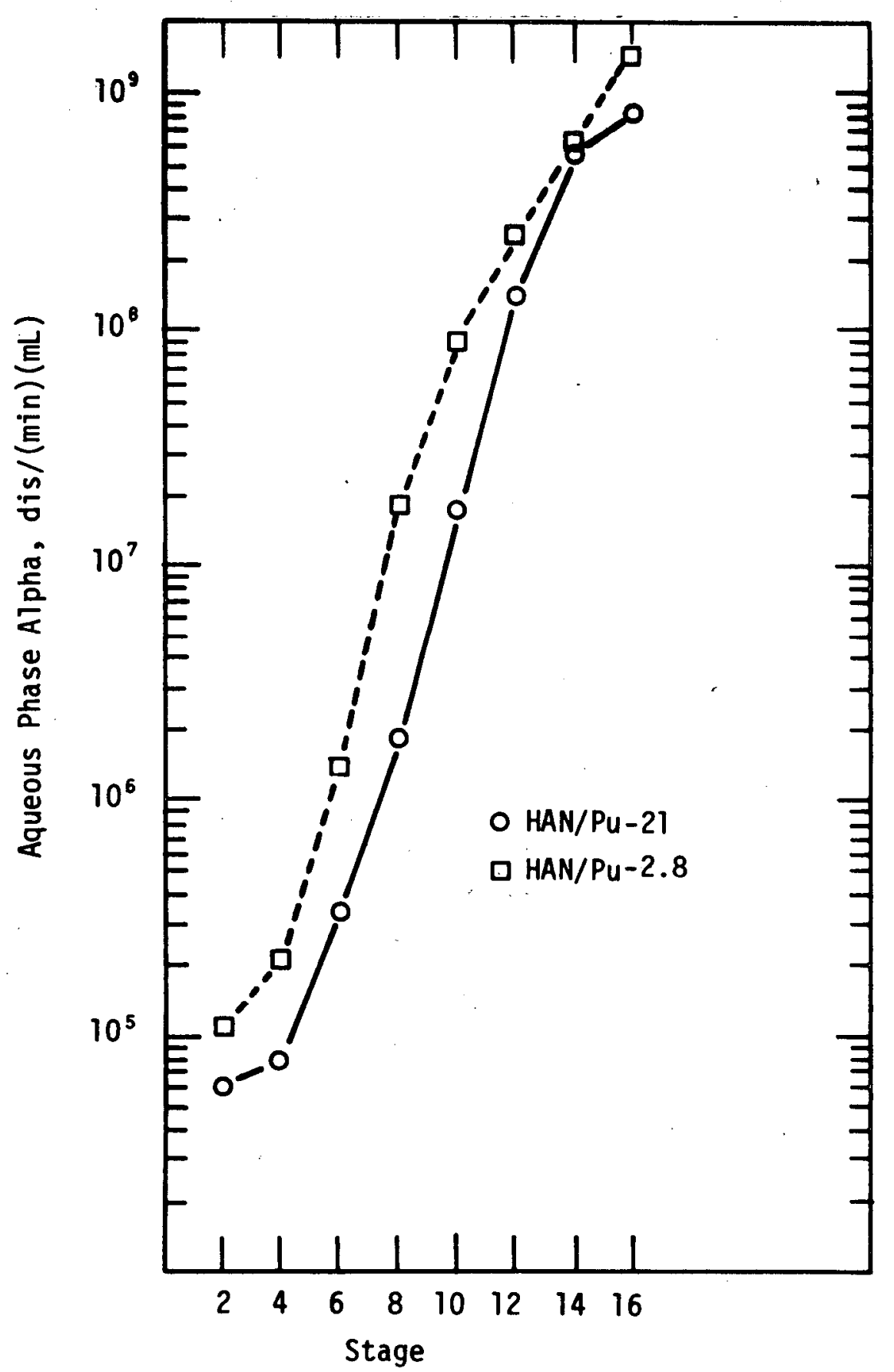

FIGURE 10. Aqueous Plutonium Profiles at Different HAN/Pu Ratios 
TABLE 11

Effect of HAN/Pu Ratio on \% Pu Loss

$\begin{array}{lll}H A N / \text { Pu } & \% \text { Pu Loss } & \frac{\Delta P u(I V)}{\Delta H A N} \\ 13 & <0.03 & 2.0 \\ 7.4 & <0.03 & 1.3 \\ 2.8 & 0.005 & 1.7\end{array}$

Previously, Barney ${ }^{7}$ reported that when HAN was present in excess (HAN/Pu $>1$ ) only Reaction 1 was significant. However, his studies were conducted in a single aqueous phase. In the heterogenous system of the mixer-settler, Reaction 2 is significant even at fairly large $\mathrm{HAN} / \mathrm{Pu}$ ratios.

\section{Effect of Nitrite}

Two miniature mixer-settler tests were made in which nitrite was added to the organic phase entering the partitioning bank. Nitrite increases the consumption of hydroxylamine, but the effect can be overcome by excess hydroxylamine. $0.007 \mathrm{M}$ nitrous acid added to the organic phase entering the partitioning bank increased plutonium losses to the uranium stream 5-fold at HAN/Pu ratio of 2.8 but did not affect losses at $\mathrm{HAN} / \mathrm{Pu}$ ratio of 7.1 (Table 12). The effect of nitrous acid is greater than shown by the increased losses. Figure 11 shows the difference in stage concentrations. Plutonium inventory in the mixer-settler increased dramatically either due to destruction of hydroxylamine by nitrous acid (Reaction 3$)^{10}$ or reoxidation of $\mathrm{Pu}^{3+}$ by nitrous acid (Reaction 4).

\section{TABLE 12}

Effect of Nitrite - 0.007M $\mathrm{HNO}_{2}$ in $\mathrm{BF}$

Initial HAN/Pu \% Pu Loss
2.8
0.026

7.1

0.005 


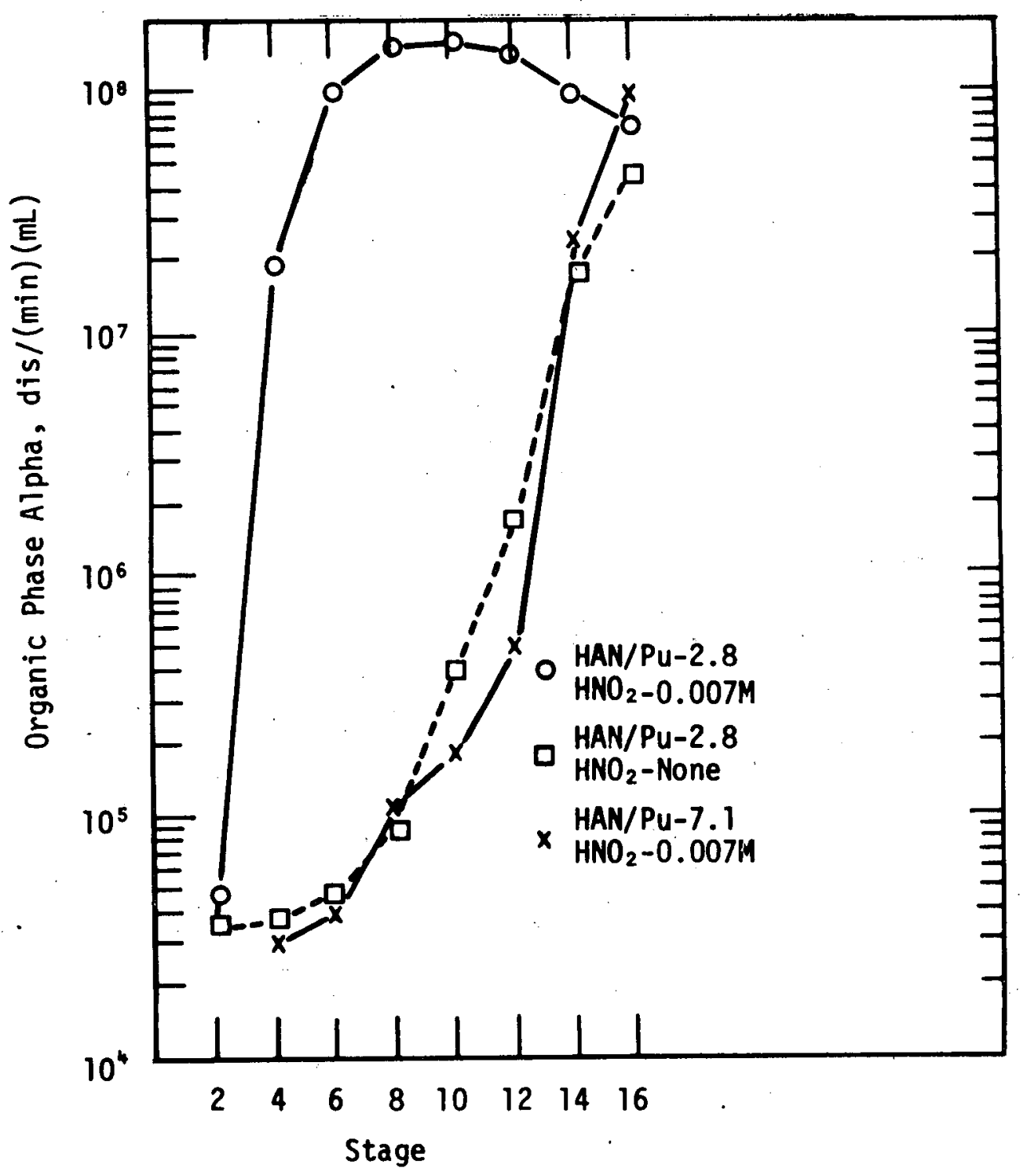

FIGURE 11. Effect of Nitrite on Plutonium Profiles in B. Mixer-Settler 


$$
\begin{aligned}
& \mathrm{HNO}_{2}+\mathrm{NH}_{3} \mathrm{OH}^{+} \rightarrow \mathrm{N}_{2} \mathrm{O}+2 \mathrm{H}_{2} \mathrm{O}+\mathrm{H}^{+} \\
& \mathrm{Pu}^{3+}+\mathrm{HNO}_{2}+\mathrm{H}^{+} \rightarrow \mathrm{Pu}^{4+}+\mathrm{NO}+\mathrm{H}_{2} \mathrm{O}
\end{aligned}
$$

The NO produced in the reaction generates additional $\mathrm{HNO}_{2}$ (Reaction 5) to produce a chain reaction.

$$
2 \mathrm{NO}+\mathrm{HNO}_{3}+\mathrm{H}_{2} \mathrm{O} \underset{\leftarrow}{\rightarrow} 3 \mathrm{HNO}_{2}
$$

Reaction 3 has been shown to be slower than Reaction $4 .^{10}$ Thus, unless a sufficient excess of hydroxylamine is present to allow Reaction 3 to react with nitrite before it reacts with $\mathrm{Pu}^{3+}$, plutonium will reflux. A molar ratio of $\mathrm{HAN} / \mathrm{Pu}+\mathrm{HNO}_{2}$ of greater than the 1.3 used in the first test is necessary for successful partial partitioning.

\section{EXPERIMENTAL PROCEDURES}

Mixer-settler tests were made in a series of 16-stage miniature mixer-settlers described by Schlea, et al. ${ }^{11}$ Uranium was determined by colorimetry or by titration with the Davies and Gray ${ }^{12}$ method. Plutonium was determined by gross alpha and alpha pulse height analysis. In addition, approach to steady state operation was monitored in-line by gamma spectroscopy with the low energy gammas from ${ }^{238} \mathrm{Pu},{ }^{239} \mathrm{Pu}$, and ${ }^{240} \mathrm{Pu}$. Hydroxylamine was determined by reaction with excess ferric ion and subsequent potentiometric titration of ferrous ion formed in the reaction with dichromate. Nitrite was determined by reaction with excess ceric ion and titration of excess ceric with ferrous ion to a ferrous o-phenanthroline end point.

Hydroxylamine nitrate was obtained as a 16 wt $\%$ solution from Baker and Adamson Co. Diluent was obtained from SRP and consisted of a mixture $\mathrm{C}_{12}$ to $\mathrm{C}_{15}$, n-paraffin hydrocarbons with an average molecular weight of $\sim 190$. Diluent was mixed with reagent-grade 100 vol $\%$ TBP to make $30 \pm 0.2$ vol $\%$ TBP solution. The 30 vol $\%$ TBP was washed with $0.5 \mathrm{M} \mathrm{Na} \mathrm{CO}_{3}$. All other chemicals were reagentgrade and were used without further purification. 


\section{REFERENCES}

1. W. Oschsenfeld and H. Schmieder (to Gessellschaft fur Kernforschung m.b.H., Karlsruhe, Germany). Method of Stripping Plutonium from Tributyl Phosphate Solution Which Contains Dibutyl Phosphate-Plutonium Stable Complexes. U. S. Patent 3,949,049 (April 6, 1976).

2. A. M. Rozen and M. Ya. Zel'venskii. "Mathematical Simulation of Processes in the Extractive Reprocessing of Nuclear Fue1 4. Separation of Uranium and Plutonium by the Method of Displacement Re-extraction." Sov. At. Ener. 41, 91 (1976).

3. "Physical Protection of Unclassified Special Nuclear Materials." ERDA Manual 2405-0502.

4. S. B. Watson and R. H. Rainey. Modifications of the SEPHIS Computer Code for Calculating the Purex Solvent Extraction System. USERDA Report ORNL-TM-5123, Oak Ridge National Laboratory, Oak Ridge, TN (1975) .

5. Strategy of Experimentation. E. I. du Pont de Nemours and Co., Wilmington, DE, p 29 (October 1975).

6. V. L. Schuelein. Parameters for Plutonium Polymer Formation in Nitric Acid. USERDA Report ARH-SA-233, Richland, WA (1975).

7. 6. S. Barney. "A Kinetic Study of the Reaction of Plutonium(IV) with Hydroxylamine." J. Inorg. Nucl. Chem. 38, 1677 (1976).

8. Light Water Reactor Fuel Reprocessing Quarterly Report, USERDA Report DP-AFCT-77-1-6, E. I. du Pont de Nemours and Co., Savannah River Laboratory, Aiken, SC, p 29 (April - June 1977).

9. P. Patigny, J. Regnier, P. Mique1, and D. Taillard. International Solvent Extraction Conference, Lyon, France 2974. p 2019, Society of Chemical Industry, London (1974).

10. G. L. Richardson and J. L. Swanson. Plutonium Partitioning in the Purex Process with Hydrazine-Stabilized Hydroxylamine Nitrate. USERDA Report HEDL-TME-75-31, Westinghouse Hanford Co., Hanford Engineering Laboratory, Richland, WA (1975).

11. C. S. Schlea, M. R. Caverly, E. C. Horni, H. E. Henry, and W. J. Jenkins. A Miniature Pilot Plant for Prucessing Irradiated Nuclear Fuel. USAEC Report DP-757, E. I. du Pont de Nemours and Co., Savannah River Laboratory, Aiken, SC (1962).

12. A. R. Eberle, M. W. Leoner, C. G. Goldbeck, and C. J. Rodden. Titrimetric Determination of Uranium in Products, Fuel, and Scrap Materials After Ferrous Ion Reduction in Phosphoric Acid, Part I. USAEC Report NBL-252, New Brunswick Laboratory, New Brunswick, NJ (July 1970). 


\section{APPENDIX A}

\section{Statistical Calculations}

A 40-run Plackett-Burman screening design ${ }^{5}$ was used to determine the statistical significance of 10 process parameters in controlling the concentration factor (CF). Each parameter was assigned a high and low value. With the SEPHIS computer code, concentration factors were calculated for forty tests with different combinations of high and low parameter values.

The effect of a variable (or unassigned factor) was calculated as:

$$
\text { Effect }=\frac{C F(\text { variable }+)-C F(\text { variable }-)}{2}
$$

The minimum statistically significant effect was calculated as

$$
\begin{aligned}
\text { MIN }= & t \cdot S_{F E} \\
t= & +- \text { distribution with degrees of factor equal to } \\
& \text { number of unassigned factor effects } \\
S_{F E}= & 1 / q \text { (unassigned factor effect) }{ }^{2} \frac{1}{2} \\
q= & \text { Number of unassigned factor effects }
\end{aligned}
$$

Any factor effect whose absolute value is larger than MIN is statistically significant. 